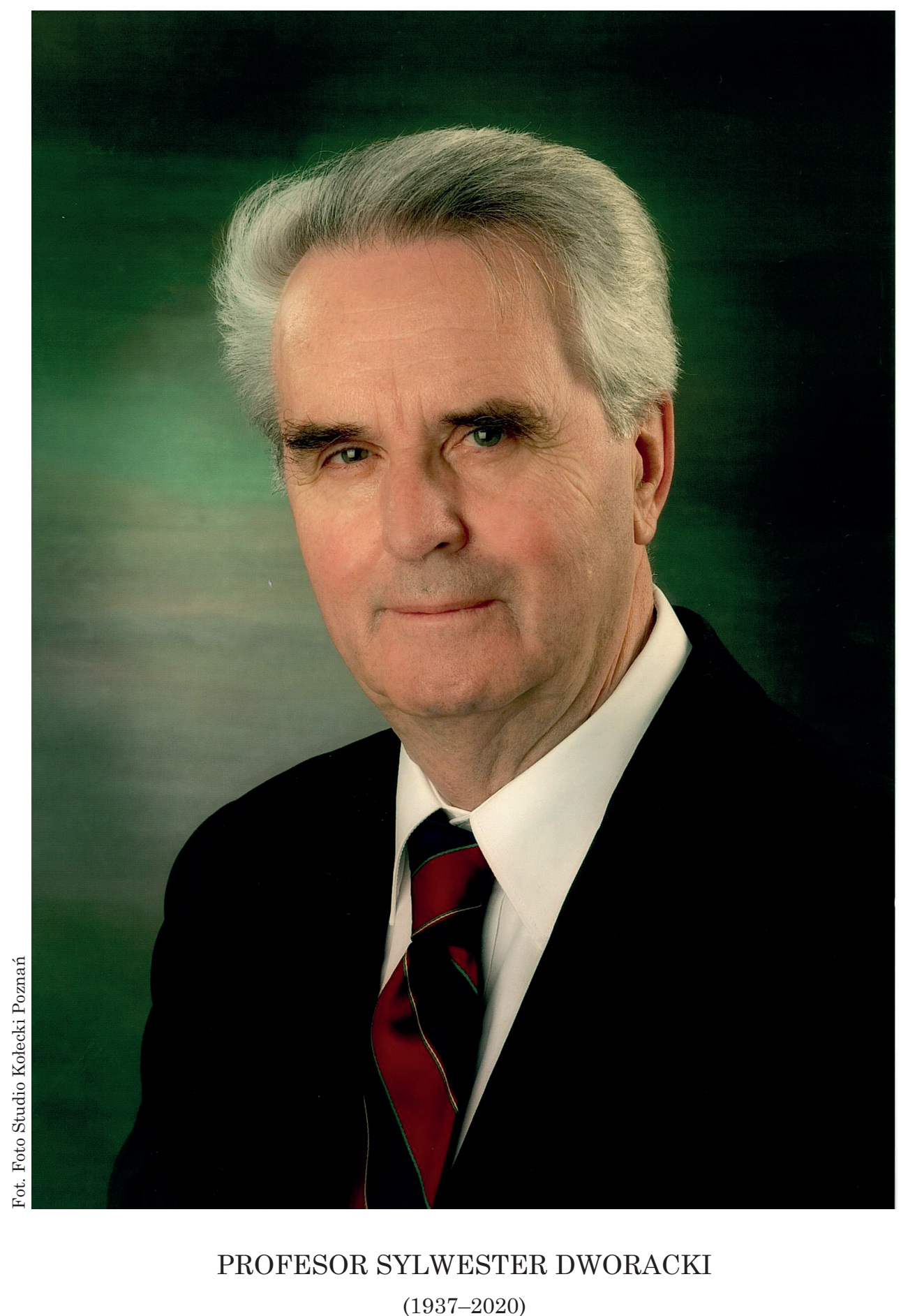



Anna Krajewska

\section{Biały bez. Pożegnanie Profesora Sylwestra Dworackiego}

ABSTRACT. Krajewska Anna, Biały bez. Pożegnanie Profesora Sylwestra Dworackiego [White lilac. Farewell to Professor Sylwester Dworacki]. „Przestrzenie Teorii” 34. Poznań 2020, Adam Mickiewicz University Press, pp. 411-413. ISSN 1644-6763. DOI 10.14746/pt.2020.34.20.

A text dedicated to the memory of Professor Sylwester Dworacki, a member of the Editorial Committee of the journal "Przestrzenie Teorii” [Spaces in Theory].

KEYWORDS: remembrance, Professor Sylwester Dworacki, farewell, Editorial Board of "Przestrzenie Teorii"

12 października 2020 roku odszedł od nas prof. dr hab. Sylwester Dworacki. Człowiek Uniwersytetu, nie tylko dlatego, że pełnił w Uniwersytecie im. Adama Mickiewicza wiele ważnych funkcji: Kierownika Zakładu Hellenistyki (w latach 1977-1987), Pracowni Prozy Greckiej od 1999 roku, zastępcy Dyrektora Instytutu Filologii Klasycznej (w latach 1977-1981 oraz 1988-1993), Prodziekana Wydziału Filologicznego (1982-1985), Prorektora UAM w latach 1993-1999, ale przede wszystkim dlatego, że ideę Uniwersytetu jako wspólnoty wartości, myślenia, działania nosił w sobie i ją realizował w kontaktach z ludźmi uczelni i poza nią. Wybitny Uczony (nie tylko dlatego, że był cenionym specjalistą w zakresie literatury greckiej, wydał wiele książek, ważnych artykułów, przekładów, recenzji, ale dlatego, że umiał się swoją wiedzą wspaniale dzielić, przekazując ją studentom i nam wszystkim w rozmowach, w niestereotypowych reakcjach na rozmaite sytuacje komentowane sentencjami z greki lub łaciny, cytowanymi fragmentami ze sztuk antycznego teatru). Utalentowany muzycznie (współpracował z Festiwalem Chórów Uniwersyteckich), świetny Wykładowca (wykładał w wielu ośrodkach uniwersyteckich za granica, był stypendystą Harvard University), znakomity Redaktor (jako wieloletni członek Redakcji, a od 1983 roku naczelny redaktor ważnego czasopisma filologów klasycznych „Eos” oraz członek Komitetu Redakcyjnego „Przestrzeni Teorii” od momentu powstania pisma w 2002 roku).

Bardzo trudno jest pisać o osobie, do której już nie można zatelefonować, wysłać e-maila, podzielić się refleksjami podczas zebrań Rad Wydziału, zapytać o jakiś fakt dotyczący kultury antycznej na korytarzu uczelni... Bardzo trudno jest pisać o serdecznym Przyjacielu, który współredagował 
od początku powstania w 2002 roku nasze wspólne „Przestrzenie Teorii”. A teraz, kiedy ostatni przekazany Profesorowi numer czasopisma pozostał bez odpowiedzi, bez komentarza, odczuwam wokół jakaśs „pustą przestrzeń”, puste miejsce w Redakcji, puste miejsce na scenie teorii. Choć wiem, że już nie otrzymam w kolejnym e-mailu paru zdań na „tematy przestrzenne", jak skrótem czasem mówiliśmy, jednak wciąż czekam na te słowa z napięciem... jakby miało być tak, jak zawsze: refleksja, nowy pomysł, uwaga... Wzięłam dziś do ręki pięknie wydaną książkę, którą wraz z dedykacją otrzymałam od Profesora: Heliodor, Opowieść etiopska o Theagenesie $i$ Chariklei. Spojrzałam na datę dedykacji - styczeń 2002 rok, a więc wtedy, gdy zaczęliśmy razem wydawać „Przestrzenie Teorii”. Miałam zawsze w Profesorze Dworackim ogromne wsparcie, zarówno wtedy, gdy pomysł czasopisma zaczynał się realizować, jak i wtedy, gdy kolejne numery wymagały coraz to więcej pracy i doświadczenia. Zawsze mogłam liczyć na cenne rady i kompetencję rzetelnego i pomysłowego Badacza, Tłumacza, Redaktora, i to zarówno w chwilach moich radości i euforii, jak i zwątpienia, zmęczenia, niewiary. Przerzucam dziś karty tłumaczenia Heliodora i nagle dostrzegam - wprowadzoną już na wydrukowanej książce - poprawkę, naniesioną ołówkiem, dokonaną ręką Profesora. W przedostatnim wersie na stronie IX w nazwie postaci Cyrusa Młodszego zostało przekreślone słowo Młodszego i wpisane Starszego. Ta poprawka, korekta autorska, brzmi jak celowy zabieg korekcji, jakbym słyszała głos Sylwestra Dworackiego, „nie, nie, co piszę, Starszego".

Bogatą twórczość naukową Profesora Dworackiego odnotowują liczne opracowania, artykuły, bibliografie sporządzane przez wybitnych znawców przedmiotu, filologów klasycznych (żeby wymienić na przykład artykuł Profesora Jerzego Danielewicza Nasz Profesor Sylwester Dworacki, opublikowany w czasopiśmie „Symbolae Philologorum Posnaniensium” 2008 roku z okazji 70. urodzin Jubilata). Do takich bogatych i pięknych charakterystyk odnosić się nie sposób.

Zatem podejmę w tym miejscu inny rodzaj pisania, który sprowadzać się będzie jedynie do rzutu spojrzenia wstecz, do błysku pamięci, chwili utrwalonej w zastygłym geście. Odejście osoby na swój sposób bliskiej myślowo, przyjacielskiej, serdecznej, życzliwej powoduje, że czasem chcę się odwrócić i patrząc wstecz, zobaczyć w jednej chwili, w jednym spojrzeniu, w jednym momencie jakiś pojedynczy gest, rys, cechę, która Go utrwaliła, zamknęła w jakiejśs tylko mojej, własnej formule, w świecie indywidualnej pamięci.

Z Profesorem Dworackim łączyło mnie zainteresowanie dramatem, komedia, scena (tyle, że tak bardzo odległymi w czasie, jak dystans od epoki komedii Menandra do okresu komedii „nienapisanej” Różewicza). A jednak spotykaliśmy się i w tych dramaturgicznych przestrzeniach, np. podczas 
dawnej teoretycznoliterackiej konferencji w Kołobrzegu poświęconej dialogowi w kulturze. Profesor nie odmówił mojego zaproszenia i wraz z grupa klasyków stał się podporą sesji naukowej polonistów, otwierając nam oczy na skomplikowane problemy związane między innymi z parabaza w komedii staroattyckiej. Dla teoretyków literatury, „współcześników”, znających przeważnie pojęcie parabazy raczej z pism Paula de Mana niż z teatralnej sceny - „przerwanie dyskursu” zaczęło znaczyć w zupełnie innych kontekstach. Pojęcia antyczne pojawiające się w referatach na wspomnianej konferencji, jak np. diegema dramatikon, stały się punktami odniesień wielu naszych dyskusji i sporów, a potem tekstów poświęconych współczesności i ksiażki o dramatyczności i dialogowości w kulturze. Tamte agony, tamte dysputy sprzed wielu lat sa wspominane przez wielu literaturoznawców i teatrologów z różnych ośrodków uniwersyteckich do dziś.

Spotkania z Profesorem rozkwitały także w przestrzeniach Internetu. Jakże cieszyły mnie nasze dyskusje o problemie „iluzyjności iluzji w komedii”, o „dramacie jako debacie, podobnej nieraz do tej, która miała miejsce naprzeciw teatru na Pnyksie, tam, gdzie odbywały się zgromadzenia Ateńczyków" itp. Pewnego dnia Profesor, komentując fragment mego wstępu do kolejnego numeru „Przestrzeni Teorii”, nawiązującego do anegdoty Sokratesa o Talesie, idei Platona, problemu odbicia i teorii, napisał: „Patrzyłem kiedyśs na pięknie odnowiony budynek nad Warta [...] i ten sam budynek zniekształcony w głębi rzeki. Im głębiej, tym większe zniekształcenie, albo inaczej: im coś wyższe, tym bardziej zniekształcone. Przez co? Przez niestabilne lustro wody. My jesteśmy tym niestabilnym lustrem, które w różny sposób odbija to, co stabilne. W ten sposób tłumaczę studentom [...] świat niezmiennych idei Platona i jego odbicie w naszej świadomości”"

Ostatnia moja, mailowa korespondencja z Profesorem Dworackim, nie dotyczyła jednak, jak można było sądzić, wyłącznie tekstów „z antykiem w tle", ale przyrody i teorii, refleksji filozoficznych i... ogrodów... W maju przysłał mi zdjęcie kwiatów ze swego ogrodu; amarantową piwonię i piękny, biały bez.

W imieniu Komitetu Redakcyjnego „Przestrzeni Teorii” żegnamy Cię Sylwestrze, Przyjacielu, Redaktorze, nasz Profesorze. Odwracając toposy życia jako fikcji, ułudy, snu, teatru, można by powiedzieć, że życie to tylko parabaza w metafizycznym spektaklu niewiadomego i nierozstrzygalnego, złamanie na moment iluzji scenicznej, po to, by móc zobaczyć, choć przez chwilę, realny, kwitnący biały bez...

Drogi Panie Profesorze, odpoczywaj w pokoju.

${ }^{1}$ Wszystkie cytaty w tym akapicie pochodzą z naszej korespondencji mailowej. 
